\title{
PENGARUH PENGHARGAAN DAN MOTIVASI KERJA TERHADAP KINERJA KARYAWAN PT. ANARA TRISAKTI MEDIKA JAKARTA TIMUR
}

\author{
Fahri Ibnu Rezani ${ }^{1)}$ \\ 1) Mahasiswa Program Studi Manajemen FE UNKRIS \\ Ella Siti Chaeriah ${ }^{2)}$ \\ 2) Dosen Program Studi Manajemen FE UNKRIS \\ Alamat: Kampus UNKRIS, Jatiwaringin Jakarta Timur \\ Email: ellasiti@gmail.com
}

\begin{abstract}
This study aims to examine the effect of rewards and work motivation on employee performance. This research was conducted at a medical equipment company in East Jakarta. Data collection was carried out using a questionnaire to respondents. This research was tested with validity and reliability test, classic assumption test, and simple and multiple linear regression analysis test. The results of this study partially giving awards a positive and significant effect on the performance of employees of PT. Anara Trisakti Medika East Jakarta, work motivation has a positive and significant effect on the performance of the employees of PT. Anara Trisakti Medika East Jakarta, and giving awards and work motivation together have a positive and significant effect on the performance of the employees of PT. Anara Trisakti Medika East Jakarta.
\end{abstract}

Keywords: Rewards, work motivation, employee performance

\section{PENDAHULUAN}

Pada zaman yang berkembang ini banyak sekali muncul perusahaan perusahaan baru, perusahaan tersebut beraneka ragam mulai dari sektor pertanian, perikanan, jasa, perbankan, tekstil, produksi dan sebagainya. Setiap perusahaan tentunya ingin mencapai tujuannya, yaitu menjadikan perusahaan semakin berkembang pesat dan sanggup untuk bersaing dengan perusahaanperusahaan lainnya. Namun ada hal yang sangat perlu diperhatikan bahwa pencapaian suatu tujuan perusahaan tidak lepas dari teknologi dan peran setiap individunya. Individu dapat dikategorikan sebagai sumber daya manusia, sumber daya manusia tersebut sangat menunjang kinerja perusahaan. Setiap individu memiliki peran dan tujuan masing-masing dalam pekerjaannya, bahkan setiap individu juga memiliki kemampuan dan batasanbatasan yang beragam.

Dalam menjalankan aktivitas manajemen, selalu memerlukan orang lain sebagai tenaga operasional yang melaksanakan kegiatan-kegiatan yang telah ditetapkan. Oleh karena itu, manajemen harus dapat menggerakkan sekelompok manusia untuk bekerja dengan penuh kemauan untuk mencapai tujuan yang telah ditetapkan. Akan tetapi, mengingat setiap manusia memiliki motif, emosi, aspirasi, serta kepentingan yang berbeda-beda sering kali upaya manajemen dalam menggerakkan orang lain mendapatkan berbagai hambatan. Pada dasarnya, perusahaan tentu membutuhkan karyawan sebagai tenaga kerja yang meningkatkan produk dan layanan yang berkualitas. Mengingat karyawan dianggap merupakan bagian 
aset perusahaan yang penting dalam memberikan kontribusi kepada perusahaan untuk memperoleh kinerja yang baik serta mampu berkompetisi.

Kinerja dapat dipengaruhi oleh beberapa faktor, yaitu faktor internal dan faktor eksternal. Faktor internal merupakan faktor yang berasal dari dalam diri pegawai, sedangkan faktor eksternal merupakan faktor pendukung pegawai dalam bekerja yang berasal dari lingkungan. Kinerja adalah proses pencapaian tujuan organisasi dan hasil dari usaha sumber daya manusia itu sendiri dalam sebuah organisasi. Kinerja karyawan yang baik sangatlah diharapkan oleh suatu perusahaan. Karena semakin banyak karyawan yang memiliki kinerja tinggi, maka produktivitas suatu perusahaan secara keseluruhan akan meningkat sehingga tujuan akan dapat dicapai dan diwujudkan. Untuk mengantisipasi berbagai hambatan yang dialami oleh pihak manajemen tersebut, diperlukan adanya pemberian reward atau penghargaan serta motivasi kerja yang mendukung bagi karyawan.

Penghargaan (reward) merupakan salah satu faktor penting yang dapat mempengaruhi kinerja karyawan, apabila perusahaan tidak memperhatikan penghargaan kepada karyawan, ini akan berdampak akan menurunnya kinerja para karyawan, tetapi tentunya penghargaan juga diberikan kapada karyawan yang mempunyai prestasi kerja yang cukup baik. Dengan adanya penghargaan yang mendukung akan dapat peningkatan kinerja karyawan sehingga pencapaian tujuan yang telah ditetapkan perusahaan dapat tercapai. Hasil penelitiannya membuktikan bahwa peran penghargaan berpengaruh positif dan signifikan terhadap produktivitas kerja pegawai. Penghargaan merupakan ganjaran, upah, hadiah. Dengan demikian disimpulkan penghargaan atau penghargaan yakni imbalan yang diberikan baik dalam dalam bentuk material dan non material yang diberikan oleh pihak perusahaan kepada karyawannya biar mereka sanggup bekerja dengan motivasi tinggi dan berprestasi dalam mencapai tujuan perusahaan.

Kinerja yang diperoleh dari setiap individu sangat beragam, bergantung pada kemampuan masing-masing, kemampuan tersebut tentunya didorong oleh motivasi dalam diri setiap individu, motivasi yaitu kemampuan diri sendiri yang timbul karena kemauan. Motivasi timbul dalam diri seseorang karena berbagai macam faktor. Motivasi merupakan suatu dorongan kehendak yang menyebabkan seseorang melakukan suatu perbuatan untuk mencapai tujuan tertentu. Pada umumnya, motivasi bisa diperoleh dari dalam diri sendiri dan melalui orang lain. Dengan adanya motivasi, maka seseorang akan memiliki kekuatan atau tenaga untuk melakukan tindakan tertentu tanpa adanya paksaan.

Tujuan penelitian ini adalah untuk mengetahui pengaruh penghargaan dan motivasi kerja terhadap kinerja karyawan PT. Anara Trisakti Medika Jakarta Timur.

\section{LANDASAN TEORI}

\section{Penghargaan}

Penghargaan seperti yang disampaikan oleh Simamora, (2006) merupakan insentif yang mengaitkan bayaran atas dasar untuk sanggup meningkatkan produktivitas para karyawan guna mencapai keunggulan yang kompetitif. Penghargaan adalah kegiatan dimana organisasi menilai kontribusi karyawan dalam rangka untuk mendistribusikan penghargaan moneter dan non moneter cukup langsung dan tidak langsung dalam kemampuan organisasi untuk membayar berdasarkan peraturan hukum (Schuler, et, al 2011). Penghargaan adalah semua pendapatan yang berbentuk uang, barang langsung 
atau tidak langsung yang diterima karyawan sebagai imbalan atau jasa yang diberikan kepada perusahaan (Hasibuan, 2013).

Penghargaan berarti "semua bentuk penggajian atau ganjaran kepada karyawan dan timbul karena kekaryawanan mereka". Dapat berupa pembayaran uang secara langsung (upah, gaji, insentif, bonus) dan dapat pula berbentuk pembayaran tidak langsung (asuransi, liburan atas biaya luwes, kantor yang bergengsi, pekerjaan yang lebih menantang), (Dessler, 2011).

Program penghargaan penting bagi organisasi karena mencerminkan upaya organisasi untuk mempertahankan sumber daya manusia sebagai komponen utama dan merupakan komponen biaya yang paling penting. Disamping pertimbangan tersebut, "penghargaan juga merupakan salah satu aspek yang berarti bagi karyawan, karena bagi individu datau karyawan besarnya penghargaan mencrminkan ukuran nilai karya mereka diantara para karyawan iru sendiri, keluarga, dan masyarakat". (Sulistiyani dan Rosida, 2011)

Empat faktor yang harus dijadikan dasar dalam mempertimbangkan kebijakan penghargaan. Menurut Nawawi (2008), yaitu "konsistensi Internal, persingan/kompetisi ekternal, kontribusi karyawan, administrasi", konsisten internal yang kadang-kadang disebut dengan keadilan internal merujuk kepada pekerjaan atau tingkat keahlian didalam sebuah perusahaan, yang membandingkan kontribusi mereka dalam pencapaian tujuan organisasi.

Dengan perkataan lain konsistensi internal merupakan penetapan pemberian penghargaan yang didasarkan pada perbandingan jenis-jenis pekerjaan didalam perushaan. Untuk itu perlu, maka perlu dilakukan analisa jabatan, uraian pekerjaan/tugas, evaluasi pekerjaan/tugas dan job structur untuk menentukan besarnya imbalan untuk tiap-tiap jenis pekerjaan. Konsistensi internal menjadi salah satu faktor yang menentukan semua tingkatan imbalan pekerjaan yang sama, maupun semua pekerjaan yang berbeda.

Pada kenyataannya, perbedaan penghargaan yang diberikan sesuai kinerja masing-masing karyawan merupakan salah satu kunci yang menantang para manajer. Kompetisi eksternal adalah penetapan besarnya penghargaan pada tingkatan dimana perusahaan masih memiliki keunggulan kompetitif dengan perusahaan lain sehingga perusahaan dapat mempertahankan karyawan yang memiliki keunggulan/berkualitas untuk tetap bekerja diperusahaan. Kontribusi karyawan merupakan penetapan besarnya penghargaan yang merujuk kepada kontribusi yang telah diberikan karyawan kepada perusahaan. Pernghargaan dapat ditetapkan berdasarkan senioritas, prestasi kerja, panduan insentif, dan program yang ada di dalam perusahaan.

Tipologi penghargaan dapat dibedakan antara penghargaan ekstrinsik dan penghargaan intrinsik. Penghargaan ekstrinsik merupakan penghargaan finansial, materiil atau penghargaan sosial karena berasal dari lingkungan. Sementara itu, penghargaan psikis merupakan penghargaan intrinsik karena bersifat self-granted. Seseorang pekerja yang bekerja mencari penghargaan ekstrinsik, seperti uang ataupun pujian dikatakan termotivasi secara ekstrinsik, sedangkan mereka yang memperoleh kesenangan dari tugas-tugas atau pengalaman nerasa kompeten atau menentukan diri sendiri dikatakan termotivasi atau bersemangat secara intrinsik.

Menurut Hamzah, (2012) ada beberapa indikator dari penghargaan yaitu: 1). "Insentif yang diberikan; Pemberian insentif kepada karyawan bertujuan untuk meningkatkan motivasi karyawan untuk melaksanakan pekerjaan yang baik. Dengan meningkatkan 
semangat karyawan dalam melaksanakan pekerjaan, tentunya akan berpengaruh terhadap produktivitas kerja oleh sebab itu manfaat insentif sangat perlu diperhatikan oleh perusahaan yang ingin berkembang. 2). Kenaikan pangkat; Karyawan kompeten yang mempunyai produktivitas kerja yang tingggi dan mampu bekerja dengan baik yang dapat menjalankan tujuan perusahaan, salah satu penghargaan yang tepat diberikan kepadanya yaitu kenaikan pangkat yang sesuai dengan peraturan perusahaan. Dimana ia diletakkan dengan tujuan untuk lebih bisa lagi mengembangkan perusahaan. 3). Pendidikan dan pelatihan; Pendidikan dan pelatihan salah satu hal yang besar pengaruhnya terhadap peningkatan produktivitas kerja karyawan. Semakin tinggi pendidikan karyawan, semakin besar ia dapat bekerja dengan efektif dan efisien sehingga mampu untuk meningkatkan prestasinya kejenjang yang lebih baik dan lebih tinggi lagi. 4). Motivasi dan tujuan; motvasi dan tujuan yang diberikan dari pimpinan kepada karyawan merupakan hal yang sangat sederhana tetapi sangat besar sekali pengaruhnya terhadap karyawan tersebut. Mereka sangat diperhatikan oleh atasannya dan ini juga salah satu peningkatan produktivitas kepada karyawan untuk bekerja lebih baik.

\section{Motivasi Kerja}

Motivasi menurut Flippo (2011) adalah suatu bentuk keahlian dalam mengarahkan seorang pegawai atau sebuah organisasi untuk mencapai keberhasilan dalam bekerja sehingga tujuan dari organisasi dapat tercapai. Menurut Winardi, (2011), motivasi sebagai hasil sebuah proses yang bersifat internal atau eksternal bagi seorang individu, yang menyebabkan timbulnya sikap antusiasme dan persistence dalam hal melaksanakan kegiatan-kegiatan tertentu. Rumusan definisi tersebut menaggapi perbincangan yang berlangsung dalam bidang riset motivasional, tentang mengapa seseorang dapat bersifat antusias dan tersistence dalam hal melaksanakan tugas. Salah satu pandangan mengatakan bahwa kebutuhan-kebutuhan yang tidak dapat di observasi (kebutuhan internal) memotivasi pelaku.

Seseorang yang termotivasi, yaitu orang-orang yang melaksanakan upaya subtansial guna menunjang tujuan-tujuan produksi kesatuan kerjanya dan organisasi tempat seseorang bekerja. Seseorang yang tidak termotivasi hanya memberikan upaya minimum dalam hal bekerja. Konsep motivasi merupakan sebuah konsep peting dalam studi tentang kinerja individual. Motivasi merupakan sebuah determinan penting bagi kinerja individual. Motivasi bukan satu-satunya determinan, karena masih ada variabelvariabel yang turut memengaruhinya, seperti: (a). Upaya (kerja) yang dikerahkan; (b). Kemampuan orang yang bersangkutan; (c). Pengalaman (kerja) sebelumnya.

Ivanko (2013) mendefinisikan motivasi "sebagai keinginan dan energi seseorang yang dikerhkan untuk pencapaian suatu tujuan". Motivasi adalah sebab dari tindakan. Upaya memengaruhi seseorang dalam rangka memberikan motivasi berarti mendapatkan kemudian ingin berbuat sesuatu yang diketahui dan seharusnya dilakukan. Motivasi dapat berupa motivasi intrinsik dan motivasi ekstrinsik. Motivasi intrinsik contohnya kepuasan dan perasaan untuk mencapai sesuatu. Motivasi ekstrinsik contohnya imbalan,hukuman dan perolehan tujuan. Motivasi ekstrinsik disebabkan oleh insentif positif dan insentif negatif.

Pimpinan perusahaan adalah sosok yang sangat berpengaruh pada peningkatan motivasi karyawan. Teori motivasi harus dipahami oleh pimpinan, sehingga mampu mengidentifikasi apa 
yang memotivasi karyawan bekerja, hubungan perilaku kerja dengan motivasi dan mengapa karyawan berprestasi tinggi. Ada beberapa teori motivasi yang dikemukakan oleh ilmuwan yang menekuni kegiatan pengembangan teori motivasi. Berikut beberapa teori motivasi: 1). Teori Abraham Maslow dalam Mangkunegara (2015). Kebutuhan dapat didefinisikan sebagai "suatu kesenjangan atau pertentangan yang dialami antara suatu kenyataan dengan dorongan yang ada dalam diri. Kebutuhan merupakan fundamen yang mendasari perilaku karyawan". Kita tidak akan bisa memotivasi karyawan jika kebutuhan karyawan belum bisa terpenuhi oleh perusahaan. Pemenuhan motivasi harus sesuai dengan kebutuhan yang diinginkan oleh karyawan. Maslow melihat adanya kebutuhan yang harus dipenuhi oleh karyawan. Hirarki kebutuhan manusia adalah sebagai berikut: a). "Kebutuhan fisiologis. b). Kebutuhan rasa aman, c). Kebutuhan untuk rasa memiliki. d). Kebutuhan akan harga diri. c). Kebutuhan untuk mengaktualisasikan diri. 2). Teori Dua Faktor Herzberg dalam Mangkunegara, (2015). Teori ini dikembangkan oleh Hezberg, teori ini juga menggunakan teori Maslow sebagai titik acuannya. Hezberg melakukan penelitian dengan cara melakukan wawancara. Masingmasing responden diminta untuk menceritakan sesuatu yang terjadi entah itu yang menyenangkan (memberikan kepuasan) ataupun tidak menyenangkan. atau yang tidak memberikan kepuasan. Kemudian hasil wawancara itu dianalisis dengan menggunakan analisis isi untuk menentukan mana faktor yang memberikan kepuasan atau yang tidak memberikan kepuasan. 3). Teori Motivasi Berprestasi McClelland dalam Mangkunegara, (2015). McClelland, mengemukakan bahwa produktivitas seseorang sangat ditentukan oleh virus mental yang ada pada dirinya. Virus mental adalah kondisi jiwa yang mendorong seseorang yang mampu mencapai prestasinya secara maksimal. Virus mental yang dimaksud terdiri dari 3 dorongan kemampuan, yaitu: a). Need of achievement (kebutuhan untuk berprestasi). b). Need of affiliation (kebutuhan untuk memperluas pergaulan). c). Need of power (kebutuhan untuk menguasai sesuatu).

Motivasi sebagai psikologis dalam diri seseorang dipengaruhi oleh beberapa faktor, baik yang bersifat internal maupun eksternal (Sutrisno, 2011). 1). Faktor Eksternal (berasal dari luar diri karyawan) yang dapat mempengaruhi motivasi tersebut mencakup antara lain: a). Lingkungan kerja yang menyenangkan; b). Kompensasi yang memadai; c). Supervisi yang baik; d). Adanya jaminan pekerjaan; e). Status dan tanggung jawab; f). Peraturan yang fleksibel. 2). Faktor internal (berasal dari dalam diri karyawan) yang mempengaruhi pemberian motivasi pada diri seseorang, antara lain: a). Keinginan untuk dapat hidup; b). Keinginan untuk dapat memiliki; c). Keinginan untuk memperoleh penghargaan; d). Keinginan untuk memperoleh pengakuan; e). Keinginan untuk berkuasa".

Menurut Maslow yang dikutip oleh Hasibuan (2013), indikator-indikator untuk mengetahui tingkat motivasi kerja pada karyawan, yaitu : 1). Kebutuhan fisik, ditunjukan dengan: pemberian gaji, pemberian bonus, uang makan, uang transport, fasilitas perumahan, dan sebagainya. b). Kebutuhan rasa aman dan keselamatan, ditunjukan dengan: fasilitas keamanan dan keselamatan kerja yang diantaranya seperti adanya jaminan sosial tenaga kerja, dana pensiun, tunjangan kesehatan, asuransi kecelakaan, dan perlengkapan keselamatan kerja. c). Kebutuhan sosial, ditunjukan dengan: melakukan interaksi dengan orang lain yang diantaranya untuk diterima dalam kelompok dan kebutuhan untuk 
mencintai dan dicintai. d). Kebutuhan akan penghargaan, ditunjukan dengan: pengakuan dan penghargaan berdasakan kemampuannya, yaitu kebutuhan untuk dihormati dan dihargai oleh karyawan lain dan pimpinan terhadap prestasi kerja. e). Kebutuhan perwujudan diri, ditunjukan dengan sifat pekerjaan yang menarik dan menantang, dimana karyawan tersebut akan mengerahkan kecakapan, kemampuan, keterampilan, dan potensinya. Dalam pemenuhan kebutuhan ini dapat dilakukan oleh perusahaan dengan menyelenggarakan pendidikan dan pelatihan.

\section{Kinerja}

Menurut Minner (1998), kinerja didefinisikan sebagai "tingkat kebutuhan individu, sebagai penghargaan atas pekerjaan yang dilakukannya. Setiap harapan dan individu tidak jelas atau tampak samar, maka setiap individu tidak akan mengetahui secara persis apa yang diharapkannya. Gibson (2008), mendifinisikan kinerja sebagai hasil dari pekerjaan terkait dengan tujuan organisasi seperti kualitas, effisiensi, dan kriteria effektifitas kerja lainnya. Kinerja juga merupakan hasil yang telah dicapai seseorang, yang berhubungan dengan tugas dan peran yang diiakukannya. Kinerja menurut Umam (2010) adalah hasil kerja yang dicapai oleh individu sesuai dengan peran atau tugasnya dalam periode tertentu, yang dihubungkan dengan ukuran nilai atau standar tertentu dari organisasi tempat individu tersebut bekerja, sedangkan Mangkunegara (2015), mendefinisikan kinerja adalah hasil kerja secara kualitas dan kuantitas yang dicapai oleh seorang karyawan dalam melaksanakan tugasnya sesuai tanggung jawab yang diberikan kepadanya. Sementara itu, kinerja seseorang merupakan kombinasi dari kemampuan, usaha dan kesempatan yang dapat dinilai dari hasil kerjanya (Bernardin, 2010). Lebih lanjut Bernardin menjelaskan kinerja merupakan catatan outcome yang dihasilkan dari fungsi karyawan tertentu atau kegiatan yang dilakukan selama periode waktu tertentu. Kinerja suatu jabatan secara keseluruhan sama dengan jumlah (rata-rata) dari kinerja fungsi karyawan atau kegiatan yang dilakukan. Pengertian kinerja disini tidak bermaksud menilai karakteristik individu tetapi mengacu pada serangkaian hasil yang diperoleh selarna periode waktu tertentu.

Berdasarkan pendapat beberapa ahli tersebut, maka definisi kinerja sebagai hasil kerja yang dicapai oleh individu tersebut dalam suatu organisasi pada suatu periode tertentu, yang dihubungkan dengan suatu nilai atau standar tertentu dan organisasi dimana individu tersebut bekerja. Di sebagian besar organisasi, kinerja para karyawan individual merupakan faktor utama yang menentukan keberhasilan organisasi. Faktor yang mempengaruhi kinerja karyawan individual (Mathis dan Jackson, 2006) yaitu: 1). "Kemampuan individual, terdiri dari beberapa kmponen yaitu bakat, minat dan faktor kepribadian. 2). Usaha yang dicurahkan yaitu terdiri dari motivasi, etika kerja, kehadiran dan rancangan tugas. 3). Dukungan organisasi yang diterimanya terdiri dari pelatihan dan pengembangan, peralatan dan teknologi, standar kinerja, manajemen dan rekan kerja".

Ada enam katagori yang digunakan untuk mengukur tingkat kinerja karyawan secara individual (Dessler, 2011) sebagai berikut: 1). Quality, yaitu tingkat dimana hasil kerja dari karyawan yang dilakukan mendekati sempurna dalam arti ketepatan, ketelitian, dan dapat diterima dari suatu aktivitas. 2). Produkctivity, yaitu kuantitas atau jumlah yang dihasilkan secara efisien dan efektif. 3). Job khowlwdge, yaitu tingkat pengetahuan yang dimiliki oleh seorang karyawan atapun informai yang dimiliki untuk menyelesaikan pekerjaan. 
4). Reliability, yaitu tingkat dimana seorang karyawan dapat dipercaya selama menyelesaikan pekerjaan dalam hal tindak lanjut pekerjaan. 5). Availability, yaitu tingkat ketepatan waktu dari suatu aktivitas yang diselesaikan oleh karyawan dan ketepatan dalam catatan daftar kehadiran karyawan. 6). Independence, yaitu tingkat dimana seorang karyawan dapat melakukan pekerjaannya tanpa bantuan bimbingan dari pengawasnya.

Indikator untuk mengukur kinerja karyawan secara individu ada enam indikator, yaitu (Robbins, et, al, 2014): 1). Kualitas. Kualitas kerja diukur dari persepsi karyawan terhadap kualitas pekerjaan yang dihasilkan serta kesempurnaan tugas terhadap keterampilan dan kemampuan karyawan. 2). Kuantitas. Merupakan jumlah yang dihasilkan dinyatakan dalam istilah seperti jumlah unit, jumlah siklus aktivitas yang diselesaikan. 3). Ketepatan waktu. Merupakan tingkat aktivitas diselesaikan pada awal waktu yang dinyatakan, dilihat dari sudut koordinasi dengan hasil output serta memaksimalkan waktu yang tersedia untuk aktivitas lain. 4). Efektivitas. Merupakan tingkat penggunaan sumber daya organisasi (tenaga, uang, teknologi, bahan baku) dimaksimalkan dengan maksud menaikkan hasil dari setiap unit dalam penggunaan sumber daya. 5). Kemandirian. Merupakan tingkat seorang karyawan yang nantinya akan dapat menjalankan fungsi kerjanya Komitmen kerja. Merupakan suatu tingkat dimana karyawan mempunyai komitmen kerja dengan instansi dan tanggung jawab karyawan terhadap kantor.

\section{METODE PENELITIAN}

\begin{abstract}
Penelitian ini untuk menjelaskan hubungan kausalitas variabel penghargaan dan motivasi kerja. Data yang digunakan dalam penelitian ini merupakan data primer melalui pengisian kuesioner kepada para karyawan. Metode analisis yang digunakan yaitu metode analisis regresi linear sederhana dan berganda. Penelitian ini bertempat pada PT. Anara Trisakti Medika Jakarata Timur, berlokasi di Komplek Ruko Taman Pondok Kelapa Blok A No.7 Jl. Pondok Kelapa Raya, Jakarta Timur 13450. Populasi dalam penelitian ini adalah karyawan PT. Anara Trisakti Medika Jakarta Timur yang berjumlah 30 karyawan. Teknik pengambilan sampel dalam penelitian ini menggunakan teknik sampling jenuh (sensus), yaitu teknik pengumpulan sampel bila semua anggota populasi digunakan sebagai sampel (Sugiyono, 2016), berarti jumlah sampel yang digunakan adalah 30 karyawan
\end{abstract}

\section{HASIL PENELITIAN DAN PEMBAHASAN}

\section{Hasil Penelitian}

\section{Hasil uji validitas dan uji reliabilitas}

Untuk menentukan apakah variabel penghargaan dan motivasi kerja dapat dijadikan pengukur terhadap kinerja karyawan PT. Anara Trisakti Medika Jakarta Timur, perlu dilakukan pengujian terhadap varibel yang digunakan yaitu penghargaan dan motivasi kerja untuk mengetahui apakah data tersebut akurat dan dapat dipercaya. Pengujian validitas ini dilakukan untuk menguji apakah tiap butir pernyataan telah mewakili indikator yang akan diteliti, persyaratan minimum untuk dapat dikatakan valid adalah $\mathrm{r}=$ 0.30. Jadi, apabila korelasi antara butir- 
butir item pernyataan dengan skor total kurang dari 0.30, maka butiran dalam instrumen tersebut dapat dikatakan tidak valid. Uji validitas dilakukan dengan melihat korelasi antara skor masingmasing butir pernyataan dengan skor total. Dari perhitungan koefisien korelasi skor tiap butir pernyataan penghargaan dengan jumlah 8 butir pernyataan, motivasi kerja sebanyak 8 butir pernyataan dan kinerja karyawan sebanyak 10 butir pernyataan. Dari semua butir pernyataan variabel penghargaan, motivasi kerja dan kinerja karyawan hasilnya adalah valid.
Pengujian reliabilitas ini dilakukan untuk menguji seberapa jauh hasil pengukuran yang dapat diandalkan secara konsisten. Dalam tabel 1, hasil pengujian reliabilitas berikut diketahui bahwa semua variabel mempunyai alpha di atas 0.6 yang berarti bahwa semua variabel dalam penelitian ini dapat diandalkan. Berdasarkan Tabel 1, dapat dilihat dan disimpulkan bahwa nilai Cronbach's Alpha lebih besar dari 0,6 yang merupakan batas minimal koefisien reliabilitas dapat dianggap baik. Dengan demikian, dikatakan bahwa pernyataan tersebut reliabel.

Tabel 1. Hasil Uji Reliabilitas Variabel

\begin{tabular}{lcc}
\hline \multicolumn{1}{c}{ Variabel } & Cronbach's Alpha & Keterangan \\
\hline Penghargaan & 0.678 & Reliabel \\
Motivasi Kerja & 0.652 & Reliabel \\
Kinerja Karyawan & 0.790 & Reliabel \\
\hline
\end{tabular}

Sumber: Hasil pengolahan data, 2019

\section{Analisis regresi linear sederhana}

Tabel 3. Pengaruh Penghargaan Terhadap Kinerja Karyawan

\begin{tabular}{|c|c|c|c|c|c|}
\hline \multirow[b]{2}{*}{ Variabel } & \multicolumn{5}{|c|}{ Parameter } \\
\hline & $\mathbf{R}$ & $\mathbf{R}^{2}$ & Konstanta & $\begin{array}{c}\text { Koefisien } \\
\text { Regresi }\end{array}$ & Sig \\
\hline Penghargaan & 0,857 & 0,734 & 0,696 & 1,214 & 0,000 \\
\hline \multicolumn{6}{|c|}{ Pengujian Signifikan } \\
\hline \multicolumn{6}{|c|}{ t hitung $>\mathrm{t}$ tabel $=8,800>2,048$} \\
\hline
\end{tabular}

Berdasarkan Tabel 3, nilai koefisien determinasi $\left(\mathrm{R}^{2}\right)$ sebesar 0.734 , artinya penghargaan memberikan kontribusi sebesar 73,4\% kepada kinerja karyawan PT. Anara Trisakti Medika Jakarta Timur, sedangkan sisanya sebesar $26,6 \%$ disumbangkan faktor lain yang tidak diteliti, seperti motivasi kerja.

Persamaan regresi $\mathrm{Y}=0,696+$ $1,214\left(\mathrm{X}_{1}\right)$
Koefisien penghargaan bertanda positif, artinya jika ada peningkatan penghargaan, maka kinerja karyawan PT. Anara Trisakti Medika Jakarta Timur akan meningkat atau sebaliknya. Nilai $t$ hitung > t tabel $(8,800>2,048)$, maka Ho tolak, Ha terima, artinya ada pengaruh yang positif dan signifikan penghargaan terhadap kinerja karyawan PT. Anara Trisakti Medika Jakarta Timur. 
Tabel 4. Pengaruh Motivasi Terhadap Kinerja Karyawan

\begin{tabular}{lccccc}
\hline \multirow{2}{*}{ Variabel } & $\mathbf{R}$ & $\mathbf{R}^{\mathbf{2}}$ & Konstanta & $\begin{array}{c}\text { Koefisien } \\
\text { Regresi }\end{array}$ & Sig \\
\cline { 2 - 6 } & 0,727 & 0,529 & 4,538 & 1,128 & 0,000 \\
\hline Motivasi & Parameter & & \\
\hline Pengujian Signifikan & & \\
\hline t hitung > t tabel = 5,606 > 2,048 \\
\hline $\begin{array}{l}\text { Keterangan: Variabel Kinerja Karyawan } \\
\text { Sumber: data diolah 2019 }\end{array}$
\end{tabular}

Berdasarkan Tabel 4, nilai koefisien determinasi $\left(\mathrm{R}^{2}\right)$ sebesar 0.529 , artinya motivsi kerja memberikan kontribusi sebesar 52,9\% kepada kinerja karyawan PT. Anara Trisakti Medika Jakarta Timur, sedangkan sisanya sebesar $47,1 \%$ disumbangkan faktor lain yang tidak diteliti, seperti penghargaan.

Persamaan regresi $\mathrm{Y}=4,538+$ $1,128\left(\mathrm{X}_{2}\right)$
Koefisien motivasi kerja bertanda positif, artinya jika ada peningkatan motivasi kerja, maka kinerja karyawan PT. Anara Trisakti Medika Jakarta Timur akan meningkat atau sebaliknya. Nilai $\mathrm{t}$ hitung > t tabel $(5,606>2,048)$, maka Ho tolak, Ha terima, artinya ada pengaruh yang positif dan signifikan motivasi kerja terhadap kinerja karyawan PT. Anara Trisakti Medika Jakarta Timur.

\section{Analisis regresi linear berganda}

Tabel 5. Pengaruh Penghargaan dan Motivasi Kerja Terhadap Kinerja Karyawan

\begin{tabular}{lccccc}
\hline \multirow{2}{*}{ Variabel } & \multicolumn{5}{c}{ Parameter } \\
\cline { 2 - 6 } & Mult. $\mathbf{R}$ & $\mathbf{R}^{\mathbf{2}}$ & Konstanta & $\begin{array}{c}\text { Koefisien } \\
\text { Regresi }\end{array}$ & Sig. \\
\hline $\begin{array}{l}\text { Penghargaan } \\
\text { Motivasi }\end{array}$ & 0,857 & 0,735 & 0,373 & $\begin{array}{c}1,177 \\
0,048\end{array}$ & 0,000 \\
\hline
\end{tabular}

\section{Pengujian Signifikan \\ F hitung $>$ F tabel $=37,394>3,354$ \\ Keterangan: Kinerja Karyawan \\ Sumber: data diolah 2019}

Berdasarkan Tabel 5, nilai F-hitung sebesar 37,394 lebih besar dari F-tabel sebesar 3,354, maka Ho tolak, Ha terima, artinya secara bersama-sama penghargaan dan motivasi kerja berpengaruh signifikan terhadap kinerja karyawan PT. Anara Trisakti Medika Jakarta Timur. Nilai koefisien determinasi $\left(\mathrm{R}^{2}\right)$ sebesar 0.735 , artinya penghargaan dan motivasi kerja secara bersama-sama memberikan kontribusi sebesar 73,5\% kepada kinerja karyawan PT. Anara Trisakti Medika Jakarta
Timur, sedangkan sisanya sebesar $26,5 \%$ disumbangkan faktor lain yang tidak dibahas dalam penelitian ini.

Persamaan regresi $\mathrm{Y}=0,373+$ $1,177\left(\mathrm{X}_{1}\right)+0,048\left(\mathrm{X}_{2}\right)$

Koefisien penghargaan bertanda positif, artinya jika ada peningkatan penghargaan, maka kinerja karyawan PT. Anara Trisakti Medika Jakarta Timur akan meningkat atau sebaliknya dengan asumsi motivasi kerja tidak berubah. Koefisien motivasi kerja bertanda positif, artinya jika ada peningkatan motivasi 
kerja, maka kinerja karyawan PT. Anara Trisakti Medika Jakarta Timur, akan meningkat atau sebaliknya, dengan asumsi penghargaan tidak berubah.

\section{Pembahasan}

\section{Pengaruh penghargaan terhadap kinerja karyawan}

Hasil penelitian ini menunjukkan bahwa pemberian penghargaan dapat peningkatan kinerja karyawan. Hal ini dikarenakan bahwa insentif diberikan pada karyawan yang memiliki produktivits kerja yang tinggi, manfaatnya insentif perlu diperahatikan oleh perusahaan, produktivitas kerja tinggi diberikan kenaikan pangkat, karyawan yang kompeten diberikan penghargaan, diberikan kesmpatan untuk meneruskan pendidikan, perusahaan memberikan pelatihan bagi karyawan, pimpinan selalu memberikan motivsi kerja pada karyawan dan tujuannya untuk meningkatkan prouktivitas kerja karyawan. Hasil penelitian ini sesuai dengan penelitian yang dilakukan oleh Prabu, et, al (2016), yaitu menganalisis pengaruh penghargaan terhadap kinerja karyawan.

\section{Pengaruh motivasi kerja terhadap kinerja karyawan}

Hasil penelitian ini menunjukkan bahwa motivasi kerja mendorong peningkatan kinerja karyawan. Hal ini dikarenakan bahwa kebutuhan sandang dan pangan karyawan dapat terpenuhi, adanya jaminan sosial tenaga kerja, dana pensiun bagi karyawan, pengakuan atas kemampuan yang dimiliki karyawan, rasa dihormati dan dihargai oleh sesama rekan kerja dan pimpinan, diberikan kesempatan untuk pengembangan diri, dan karyawan akan mengeluarkan segala kemampuan dalam bekerja. Hasil penelitian ini sejalan dengan penelitian yang dilakukan oleh Asmara (2016), yaitu menganalisis pengaruh motivasi kerja terhadap kinerja karyawan.

\section{Pengaruh penghargaan dan motivasi kerja terhadap kinerja karyawan}

Berdasarkan hasil analisis diketahui bahwa penghargaan dan motivasi kerja mendorong peningkatan kinerja karyawan PT. Anara Trisakti Medika Jakarta Timur. Hasil penelitian ini sama dengan hasil penelitian yang dilakukan oleh Prabu, et, al (2016) dan Asmara (2016), yaitu menganalisis pengaruh penghargaan dan motivasi kerja terhadap kinerja karyawan.

\section{KESIMPULAN DAN SARAN}

\section{Kesimpulan}

Berdasarkan hasil penelitian dan pembahasan, dapat diambil kesimpulan bahwa: 1). Penghargaan berpengaruh terhadap kinerja karyawan PT. Anara Trisaksi Medika Jakarta Timur. 2). Motivasi kerja berpengaruh terhadap kinerja karyawan PT. Anara Trisaksi Medika Jakarta Timur. 3). Penghargaan dan motivasi kerja berpengaruh terhadap kinerja karyawan PT. Anara Trisaksi Medika Jakarta Timur.

\section{Saran}

1. Bagi perusahaan diharapkan dimasa yang akan datang dapat memberikan penghargaan yang lebih baik lagi, ini berkaitan dengan pemberian upah lembur bagi karyawan yang melewati jam kerja. Diharapkan upah lembur dapat dibayar tepat waktu, pemberian upah lembur yang tepat waktu diharapkan hal tersebut dapat memacu semangat kerja karyawan, sehingga dapat meningkatkan kinerja.

2. Motivasi kerja dapat berdampak dominan bagi kinerja karyawan, maka diharapkan agar karyawan PT. Anara Trisakti Medika Jakarta Timur, tetap 
konsisten dalam memberikan motivasi yang tinggi bagi karyawannya.

3. Bagi penelitian selanjutnya disarankan untuk menambah variabel-variabel lain yang lebih beragam dalam membahas terkait kinerja karyawan.

\section{DAFTAR PUSTAKA}

Asmara, Nanda Sandi. 2016. "Pengaruh Motivasi Kerja dan Penghargaan Terhadap Kinerja Karyawan CV. Daya Budaya Corporation. Jurnal: http://hdl.handle.net/123456789/657 2.

Bernardin, H.John and Russel. 2010. Human Resource Management. New York: McGraw-Hill.

Desseler G. 2011. Human resources Development. Prentice-Hall, Inc, A Simon dan Schuter Company. Alih Bahasa Benyamin Molan. Manajemen Sumber Daya Manusia. Jilid 2. Cetakan Kedua. Jakarta: Prenhallindo

Flippo, Edwin B. 2011. Personel Management, Jakarta: PT. Gelora Askara Pratama.

Ghozali, Imam. 2016. Aplikasi Analisis Multivariete: Dengan Program IBM SPSS 23. Semarang: Badan Penerbit Universitas Diponegoro.

Gibson, M. 2008. Manajemen Sumber Daya Manusia. Cetakan ke dua. Jakarta: Erlangga.

Hamzah, Nina Lamatenggo. 2012. Teori Kinerja Dan Pengukurannya. Jakarta: PT Bumi Aksara.

Hasibuan, Malayu S.P. 2013. Manajemen Sumber Daya Manusia, Cetakan Kesembilan. Jakarta: PT. Bumi Aksara.

Herzberg, Frederrick. 2003. DasarDasar Manajemen. Diterjemahkan oleh Malayu S.P Hasibuan. Edisi Kedua. Jakarta: Bumi Aksara.

Ivanko, Štefan. 2013. Modern Theory of Organization.
Ljubljana: University of Ljubljana: Faculty of Public Administration.

Mangkunegara, A.A. Anwar Prabu. 2015. Manajemen Sumber Daya Manusia Perusahaan. Bandung: Remaja Rosdakarya.

Maslow, Abraham H. 2003. Motivasi dan Kepribadian. Jakarta: Surya Grafindo.

Mathis, R.L. \& J.H. Jackson. 2006. Human Resource Management: Manajemen Sumber Daya Manusia. Terjemahan Dian Angelia. Jakarta: Salemba Empat.

McClelland, David. C. 1987. Human Motivation. New York : The Press Syndicate of University of Cambridge.

Miner, John. 1998. Organizational Behavior, Performance and Productivity. New York: Random House Business Division.

Nawawi, Hadari. 2008. Manajemen Sumber Daya Manusia Untuk Bisnis yang Kompetitif. Cetakan Keempat, Yogyakarta: Gadjah Mada University Press.

Prabu, Aldila Saga dan Wijayanti, Dewie Tri,. 2016,. "Pengaruh Penghargaan dan Motivasi Terhadap Kinerja Karyawan (Studi Pada Divisi Penjualan PT. United Motors Center Suzuki Ahmad Yani, Surabaya). Jurnal Ekonomi Bisnis dan Kewirausahaan, Vol. 5, No. 2, 2016, hal: 104-117

Robbins, Stephen P. \& Timothy A. Judge. 2014. Perilaku Organisasi, Edisi 16. Jakarta: Salemba Empat.

Schuler. et al. 2011. Manajemen Sumber Daya Manusia. Edisi Pertama. Cetakan Pertama. Jakarta: Kencana. Simamora, Henry. 2006. Manajemen Sumber Daya Manusia, Edisi 3. Yogyakarta: STIE YKPN Yogyakarta.

Sugiyono. 2016. Statikstika Untuk Penelitian. Bandung: Alfabeta. 
Sulistiyani, Ambar Teguh dan Rosidah.

Umam, Khaerul. 2010. Perilaku 2011. Manajemen Sumber Daya Manusia. Jakarta: Graha Ilmu

Sutrisno, Edy. 2011. Manajemen Sumber Daya Manusia. Jakarta: Kencana. Organisasi. Bandung: Pustaka Setia Winardi. 2011. Motivasi Pemotivasian. Jakarta: PT. Raja Grafindo Persada. 